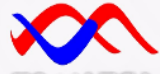

TO MAEGA

To Maega | Jurnal Pengabdian Masyarakat

Februari 2021, Vol.5, No.1, hal, 99-113

$\operatorname{ISSN}(P): 2622-6332 ; \operatorname{ISSN}(E): 2622-6340$

http://www.ojs.unanda.ac.id/index.php/tomaega

\title{
Pemberdayaan dan Peningkatan Ekonomi Masyarakat Kecamatan Marusu Melalui BUMDes
}

\author{
Marwah Yusuf ${ }^{1}$, Nur Azizah Basmar ${ }^{1}$, Lusiana Kanji 1, Eva Marin Sambo ${ }^{1}$, \\ Anwar 1, Musdalifah 1, Riska Amaliah ${ }^{1}$, M. Iksan ${ }^{1}$, Pricillia Angela Moga ${ }^{1}$ \\ ${ }^{1}$ Akuntans Ekonomi, STIEM Bongaya \\ *Correspondent Email: azizah.basmar@gmail.com
}

Article History:

Received: 17-12-2021; Received in Revised: 26-12-2021; Accepted: 18-01-2022

DOI: http://dx.doi.org/10.35914/tomaega.v5i1.965

\begin{abstract}
Abstrak
Keberadaan BUMDes belum memiliki perencanaan bisnis yang baik dan pengelolaan keuangan yang belum efektif. Hal ini menjadi masalah yang dihadapi oleh pengelola BUMDes, sehingga menghambat perkembangan BUMDes. Untuk itu perlu ada upaya untuk mengatasi permasalahan tersebut. Upaya konkrit yang perlu dilakukan adalah melakukan kegiatan pelatihan yang kemudian ditindaklanjuti dalam bentuk bimbingan teknis yang terkait dengan perencanaan bisnis dan pengelolaan keuangan. Oleh karena itu pelaksanaan kegiatan tersebut dilakukan secara bertahap yang diawali dengan dengan sosialisasi pelatihan perencanaan bisnis dan keuangan kepada pengelola BUMDes di Kecamatan Marusu. Setelah dilaksanakannya kegiatan pengabdian pada masyarakat maka kami mengambil kesimpulan sebagai berikut: 1) Perkembangan BUMDes telah berjalan dengan baik dan keberadaan BUMDes telah banyak memberikan manfaatkan bagi masyarakat setempat. 2) Pengelolaan keuangan BUMDes sebagian besar masih menggunakan sistem pembukuan manual. 3) Terdapat beberapa kendala dalam pengelolaan BUMDes yaitu kemampuan SDM yang masih rendah, pangsa pasar barang/jasa yang dihasilkan BUMDes masih terbatas, kurangnya permodalan, tidak memiliki rencana usaha dan sistem pembukuannya belum baik. 4) Kegiatan pelatihan memberikan manfaat dalam meningkatkan kemampuan dan kemudahan dalam mengelola BUMDes. 5) Tindak lanjut kegiatan diharapkan lebih teknik dalam bentuk pelatihan dan bimbingan teknis terkait dengan penyusunan rencana usaha dan teknik pembukuan keuangan BUMDes baik scara manual maupun berbasis aplikasi.
\end{abstract}

Kata Kunci: Pemberdayaan; Peningkatan Ekonomi; BUMDes

\section{Abstract}

The existence of BUMDes does not yet have a good business plan and ineffective financial management. This is a problem faced by BUMDes managers, thus hampering the development of BUMDes. For this reason, efforts need to be made to overcome these problems. Concrete efforts that need to be done are conducting training activities which are then followed up in the form of technical guidance related to business planning and financial management. Therefore, the implementation of these activities is carried out in stages, starting with the socialization of business and financial planning training to BUMDes managers in Marusu District. After carrying out community service activities, we draw the following conclusions: 1) The development of BUMDes has been going well and the existence of BUMDes has provided many benefits for the local community. 2) Most BUMDes financial management still uses a manual bookkeeping system. 3) There are several obstacles in the management of BUMDes, namely the low capacity of human 
resources, the market share of goods/services produced by BUMDes is still limited, lack of capital, does not have a business plan and the bookkeeping system is not good. 4) Training activities provide benefits in increasing the ability and convenience in managing BUMDes. 5) Follow-up activities are expected to be more technical in the form of training and technical guidance related to the preparation of business plans and financial accounting techniques for BUMDes, both manually and based on applications.

Key Word: Empowerment; economic improvement; BUMDes.

\section{Pendahuluan}

Berbagai program yang telah dicanangkan pemerintah dalam rangka mengembangkan ekonomi pedesaan. Namun, upaya tersebut belum mencapai hasil yang memuaskan. Salah satu faktor yang menghambat adalah lemahnya daya kreatif dan inovasi dalam menggerakan roda perekonomian pedesaan (Yusuf dkk, 2021). Sehingga dalam upaya pemberdayaan ekonomi pedesaan terus berhadap bantuan pemerintah dan lemahnya upaya meningkatkan kemandirian desa. Pendirian Badan Usaha Milik Desa (BUMDes) merupakan suatu upaya untuk menggerakkan sistem perekonomian desa (Slamat dkk, 2021). Dalam UndangUndang Nomor 32 Tahun 2004 menjelaskan Desa dapat mendirikan badan usaha milik desa sesuai dengan kebutuhan dan potensi desa. Kemudian dijelaskan dalam Peraturan Pemerintah Nomor 11 Tahun 2021 bahwa BUMDes adalah badan hukum yang didirikan oleh desa dan/atau hersarna desa-desa guna mengelola usaha, memanfaatkan aset, mengembangkan investasi dan produktivitas, menyediakan jasa pelayanan, dan/atau menyediakan jenis usaha lainnya untuk sebesar-besarnya kesejahteraan masyarakat Desa (Al Sukri, 2020).

Menurut PKDSP Fakultas Ekonomi Universitas Brawijaya (2007) menjelaskan BUMDes merupakan pilar kegiatan ekonomi di desa yang berfungsi sebagai lembaga sosial dan komersial. BUMDes sebagai lembaga sosial berpihak kepada kepentingan masyarakat melalui kontribusinya dalam penyediaan pelayanan social (Fadila, 2021). Sedangkan sebagai lembaga komersial bertujuan mencari keuntungan melalui penawaran sumberdaya lokal (barang dan jasa) ke pasar sehingga bisa digunakan oleh konsumen (Didiharyono dkk, 2018).

Perkembangan BUMDes di Propinsi Sulawesi Selatan pada tahun 2021 sebanyak 1.544 BUMDes dengan jenis usaha berjumlah 1.355 unit usaha dan total modal sebesar Rp.54.126.634.119 (Sumber : http://sibumdesa.com/). Dari jumlah tersebut yang tersebar di Kabupaten Maros sebanyak 42 BUMDes dengan 63 unit usaha. Rinciannya sebagai berikut. 
Tabel 1

Jumlah BUMDes dan Jenis Usaha di Kabupaten Maros

Tahun 2021

\begin{tabular}{|c|c|c|c|}
\hline No & Kecamatan & BUMDes & Unit Usaha \\
\hline 1 & Kecamatan Mandai & 4 & 9 \\
\hline 2 & Kecamatan Camba & 4 & 7 \\
\hline 3 & Kecamatan Bantimurung & 5 & 3 \\
\hline 4 & Kecamatan Maros Baru & 3 & 12 \\
\hline 5 & Kecamatan Bontoa & 6 & 4 \\
\hline 6 & Kecamatan Mallawa & 7 & 11 \\
\hline 7 & Kecamatan Tanralili & 2 & 1 \\
\hline 8 & Kecamatan Marusu & 5 & 7 \\
\hline 9 & Kecamatan Simbang & 3 & 5 \\
\hline 10 & Kecamatan Cenrana & 1 & - \\
\hline 11 & Kecamatan Tompobulu & - & - \\
\hline 12 & Kecamatan Lau & - & - \\
\hline 13 & Kecamatan Moncong Loe & 2 & 4 \\
\hline 14 & Kecamatan Turikele & - & - \\
\hline & Jumlah & 42 & 63 \\
\hline
\end{tabular}

Sumber : http://maros.sibumdesa.com/

Berdasarkan data tersebut menunjukkan bahwa pada Kecamatan Marusu terdapat 5 BUMDes dengan 7 jenis usaha, diantaraya seperti wisata pantai kuri, pengelolaan limbah sampah, serta pengelolaan Briket. Dengan dibentuknya badan usaha milik desa ini, pemerintah desa berharap dapat meningkatkan kemandirian masyarakat dan memperkuat ekonomi desa, dan juga BUMDes dapat mendorong meningkatkan Pendapatan Asli Desa (PAD) (Abidin, 2015).

Berdasarkan hasil wawancara Tim Dosen STIEM Bongaya dengan Pemerintah Kabupaten Maros pada saat melakukan survey diperoleh informasi bahwa keberadaan BUMDes belum memiliki perencanaan bisnis yang baik dan pengelolaan keuangan yang belum efektif. Hal ini menjadi masalah yang dihadapi oleh pengelola BUMDes, sehingga menghambat perkembangan BUMDes. Untuk itu perlu ada upaya untuk mengatasi permasalahan tersebut.

Keberadaan BUMDes ini diharapkan dapat memiliki penghasilan yang lebih untuk meningkatkan taraf hidup masyarakat desa sekitar. Untuk itu perlu dilakukan manajemen yang baik dalam pengelolaan keuangannya (Suwarjeni dan Jaya 2019). Untuk mempertanggung jawabkan laporan keuangan kepada masyarakat perlu dibuatkan pembukuan. Oleh sebab itu, Tim Dosen STIEM Bongaya menawarkan pelatihan pembuatan laporan keuangan untuk pertanggungjawaban keuangan BUMDes sebagai pedoman pengurus BUMDes. Outcome yang diperoleh yaitu bagian keuangan BUMDes mampu menghasilkan 
laporan keuangan BUMDes yang dapat digunakan untuk pertanggungjawaban kepada desa.

\section{Metode}

Upaya konkrit yang perlu dilakukan adalah melakukan kegiatan pelatihan yang kemudian ditindaklanjuti dalam bentuk bimbingan teknis yang terkait dengan perencanaan bisnis dan pengelolaan keuangan. Oleh karena itu pelaksanaan kegiatan tersebut dilakukan secara bertahap yang diawali dengan dengan sosialisasi pelatihan perencanaan bisnis dan keuangan kepada pengelola BUMDes di Kecamatan Marusu dengan tujuan untuk memotret dan memperoleh informasi langsung dari pengelola BUMDes mengenai permasalahan yang dihadapi dalam mengelola BUMDes dan tindaklanjut yang akan dilakukan.

Jumlah BUMDes yang ikut dalam kegiatan sebanyak 6 (enam) BUMDes dengan 29 (dua puluh Sembilan) pengelola sekaligus sebagai peserta pelatihan. Nama BUMDes tersebut sebagai berikut :

Tabel 2

Daftar BUMDes Yang Mengikuti Pelatihan

\begin{tabular}{cll}
\hline No & \multicolumn{1}{c}{ Nama BUMDes } & \multicolumn{1}{c}{ Alamat } \\
\hline $\mathbf{1}$ & Serumpun & 1. Desa A'bulosibatang \\
$\mathbf{2}$ & Sejahtera & 2. Desa Bonto Mate'ne \\
$\mathbf{3}$ & Milenial & 3. Desa Ma'rumpa \\
$\mathbf{4}$ & Mitra Tani Nelayan Lestari & 4. Desa Nisombalia \\
$\mathbf{5}$ & Benteng & 5. Desa Pa'bentengang \\
$\mathbf{6}$ & Tellumpoccoe & 6. Desa Tellumpoccoe \\
$\mathbf{7}$ & Macenning & 7. Desa Temmapadduae
\end{tabular}

Metode petaksanaan kegiatan menjelaskan solusi yang ditawarkan untuk mengatasi permasalahan yang memuat tahapan berikut ini.

\section{A. Persiapan dan Pembekalan}

1. Mekanisme pelaksanaan kegiatan

a. Pelaksanaan kegiatan melalui mekanisme sebagai berikut :

b. Pembentukan Tim pelaksana kegiatan yang terdiri dari dosen tetap dan mahasiswa program studi akuntansi

c. Tim dosen melakukan audiens dengan pemerintah setempat untuk menggali informasi tentang kondisi BUMDes setempat

2. Materi persiapan dan pembekalan Tim

a. Materi disusun sesuai dengan kebutuhan kelompok sasaran (pengelola BUMDes). Untuk itu materi pada kegiatan pelatihan keuangan BUMDes terdiri dari :

1) Pengenalan BUMDes dan Perencanaan Usaha (Busines Plan) BUMDes 
2) Teknik Pembukuan Keuangan BUMDes

b. Pembekalan Tim melalui rapat pemantapan yang dilaksanakan pada hari Senin tanggal 04 Oktober 2021 di Laboratorium Komputer Akuntansi STIEM Bongaya

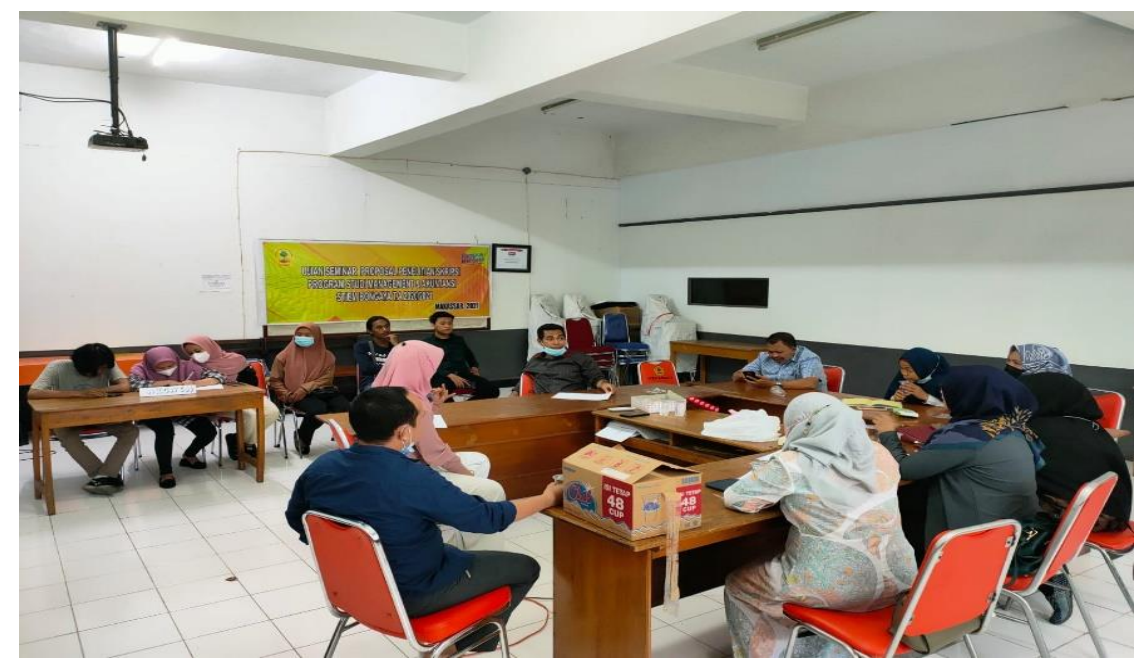

Gambar 1. Rapat Tim Dosen dan Mahasiswa Untuk Materi Pelatihan dan Persiapan Lainnya

\section{B. Pelaksanaan}

1. Langkah-Iangkah pelaksanaan kegiatan

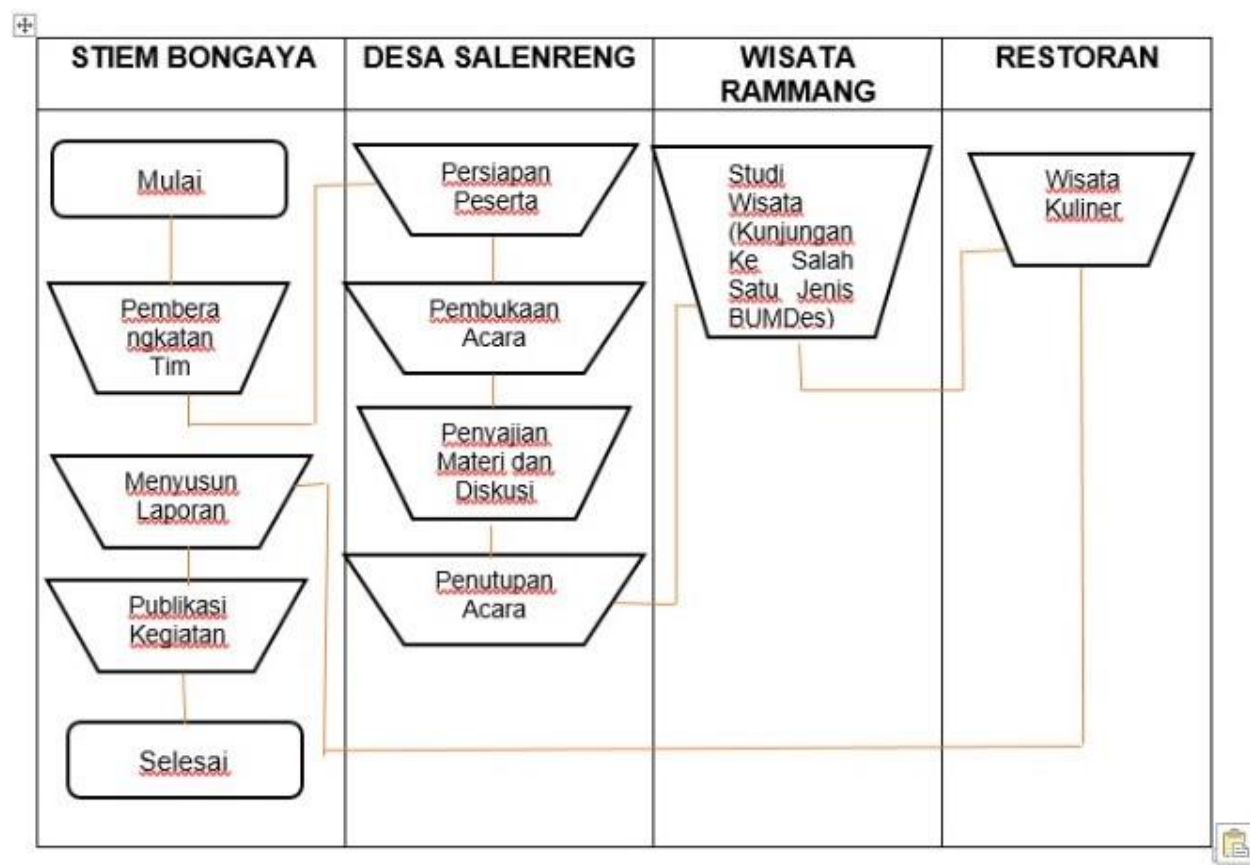

2. Metode kegiatan dalam bentuk sosialisasi tentang pentingnya perencanaan bisnis dan teknik pembukuan keuangan BUMDes, sehingga teknik penyajian materi dalam bentuk ceramah dan diskusi. 
3. Langkah-Iangkah operasional yang diperlukan untuk mengatasi permasalahan BUMDes yang terkait dengan perencanaan usaha dan teknik pembukuan dilakukan melalui kegiatan sosisialisasi, pelatihan dan bimbingan teknis.

4. Mengadakan BIMTEK

5. Membuat software pengelolaan keuangan.

\section{Hasil dan Pembahasan}

\section{A. Hasil}

\section{Analisis Kondisi Objektif BUMDes}

\section{a. Jumlah BUMDes dan Pengelola}

Jumlah BUMDes yang ikut dalam kegiatan sebanyak 6 (enam) BUMDes dengan 29 (dua puluh Sembilan) pengelola sekaligus sebagai peserta pelatihan. Nama BUMDes tersebut sebagai berikut.

Tabel 3

Daftar BUMDes Yang Mengikuti Pelatihan

\begin{tabular}{lll}
\hline No & Nama BUMDes & \multicolumn{1}{c}{ Alamat } \\
\hline $\mathbf{1}$ & Serumpun & Desa A'bulosibatang \\
$\mathbf{2}$ & Sejahtera & Desa Bonto Mate'ne \\
$\mathbf{3}$ & Milenial & Desa Ma'rumpa \\
$\mathbf{4}$ & Mitra Tani Nelayan Lestari & Desa Nisombalia \\
$\mathbf{5}$ & Benteng & Desa Pa'bentengang \\
$\mathbf{6}$ & Tellumpoccoe & Desa Tellumpoccoe \\
$\mathbf{7}$ & Macenning & Desa Temmapadduae
\end{tabular}

\section{b. Sumber Pendanaan.}

Sumber pendanaan untuk pendirian dan pengembangan BUMDes pada umumnya merupakan penyertaan modal pemerintah desa yang berasal dari Alokasi Dana Desa (ADD) dengan rata-rata Rp50.000.000200.000.000

\section{c. Manfaat BUMDes}

Keberadaan BUMDes tentunya telah banyak memberikan manfaat kepada masyarakat sekitarnya. Manfaat yang diperoleh masyarakat dengan hadirnya BUMDes diantaranya adalah dapat memperbaiki kehidupan ekonomi, dapat meningkatkan pembangunan desa dan dapat meningkatkan pembangunan desa. Hal ini seperti yang ungkapkan oleh para peserta pelatihan melalui pengisian kuesioner yang datanya disajikan dalam tabel berikut ini. 
Tabel 4

Manfaat Keberadaan BUMDes

\begin{tabular}{clcl}
\hline No & $\begin{array}{l}\text { Kondisi Perkembangan } \\
\text { BUMdes }\end{array}$ & F & $\begin{array}{l}\text { Prosen } \\
(\%)\end{array}$ \\
\hline $\mathrm{a}$ & $\begin{array}{l}\text { Memperbaiki kehidupan } \\
\text { ekonomi }\end{array}$ & 15 & $52 \%$ \\
\hline $\mathrm{b}$ & $\begin{array}{l}\text { Meningkatkan } \\
\text { pembangunan desa }\end{array}$ & 5 & $17 \%$ \\
\hline $\mathrm{c}$ & $\begin{array}{l}\text { Meningkatkan } \\
\text { pendapatan desa }\end{array}$ & 6 & $21 \%$ \\
\hline $\mathrm{d}$ & Tidak bermanfaat & 0 & $0 \%$ \\
\hline $\mathrm{e}$ & Tidak menjawab & 3 & $10 \%$ \\
\hline & Jumlah & 29 & $100 \%$ \\
\hline
\end{tabular}

\section{d. Perkembangan BUMDes}

Berdasarkan hasil wawancara dan informasi tertulis dalam bentuk kuesioner dari para pengelola sebagai peserta dalam kegiatan tersebut diperoleh informasi bahwa bahawa BUMDes yang mereka kelola berkembangan dengan baik, namun dalam pengambangan terdapat beberapa kendala yang dihadapi. Hasil analisis kondisi perkembangan BUMDes berdasarkan informasi yang diperoleh dari pengisian kuesioner seperti yang diuraikan dalam tabel berikut ini.

\section{Tabel 5}

Kondisi Perkembangan BUMDes

\begin{tabular}{clcc}
\hline No & $\begin{array}{l}\text { Kondisi Perkembangan } \\
\text { BUMdes }\end{array}$ & F & $\begin{array}{c}\text { Prosen } \\
(\%)\end{array}$ \\
\hline $\mathrm{a}$ & $\begin{array}{l}\text { Berkembang dengan baik } \\
\text { tanpa kedala }\end{array}$ & 13 & $45 \%$ \\
\hline $\mathrm{b}$ & $\begin{array}{l}\text { Berkembang dengan baik, } \\
\text { namun masih terdapat } \\
\text { kendala }\end{array}$ & 10 & $35 \%$ \\
\hline $\mathrm{c}$ & $\begin{array}{l}\text { Tidak berkembang } \\
\text { dengan baik }\end{array}$ & 3 & $10 \%$ \\
\hline $\mathrm{d}$ & Tidak menjawab & 3 & $10 \%$ \\
\hline & Jumlah & 29 & $100 \%$ \\
\hline
\end{tabular}

Lebih lanjut dijelaskan bahwa sistem pembukuan dalam mengelola keuangan BUMDes pada umumnya mereka menggunakan sistem pembukuan manual dalam mengelola keuangannya. Sebagian juga telah menggunakan sistem pembukuan berbasis aplikasi (SISKEUDES), namun dalam mengaplikasikannya masih belum efektif karena keterbatasan 
kemampuan sumber daya manusia. Bahkan ada BUMDes yang belum memiliki sistem pembukuan. Hal seperti terihat dari hasil analisis kuesiner berikut ini.

Tabel 6

Sistem Pembukuan BUMDes

\begin{tabular}{clcc}
\hline No & $\begin{array}{l}\text { Kondisi Perkembangan } \\
\text { BUMdes }\end{array}$ & F & $\begin{array}{c}\text { Prosen } \\
(\%)\end{array}$ \\
\hline $\mathrm{a}$ & $\begin{array}{l}\text { Sistem pembukuan dengan } \\
\text { Aplikasi SISKEUDES }\end{array}$ & 5 & $17 \%$ \\
\hline $\mathrm{b}$ & Sistem pembukuan manual & 19 & $66 \%$ \\
\hline $\mathrm{c}$ & $\begin{array}{l}\text { Tidak memiliki sisem } \\
\text { pembukuan }\end{array}$ & 2 & $7 \%$ \\
\hline $\mathrm{d}$ & Tidak menjawab & 3 & $10 \%$ \\
\hline & Jumlah & 29 & $100 \%$
\end{tabular}

Kemudian foktor-faktor yang dominan yang mereka alami dalam pengelolaan BUMDes adalah pangsa pasar atas produk/jasa yang dihasil BUMDes masih sangat terbatas, kemampuan sumber daya yang masih rendah dan kurangnya permodalan. Di samping itu simtem pembukuan dan rencana usaha yang belum baik juga menjai kendala dalam pengelolaan BUMDes.

Tabel 7

Kendala Pengelolaan BUMDes

\begin{tabular}{clcc}
\hline No & Faktor Penghambat & F & $\begin{array}{c}\text { Persen } \\
(\%)\end{array}$ \\
\hline a & $\begin{array}{l}\text { Kemampuan SDM yang } \\
\text { masih rendah }\end{array}$ & 6 & $21 \%$ \\
\hline b & Kurangnya permodalan & 5 & $17 \%$ \\
\hline $\mathrm{c}$ & $\begin{array}{l}\text { Tidak memiliki rencana } \\
\text { usaha yang baik }\end{array}$ & 4 & $14 \%$ \\
\hline $\mathrm{d}$ & $\begin{array}{l}\text { Sistem pembukuan yang } \\
\text { kurang baik }\end{array}$ & 3 & $10 \%$ \\
\hline $\mathrm{e}$ & $\begin{array}{l}\text { Pangsa pasar produk/jasa } \\
\text { yang terbatas }\end{array}$ & 8 & $28 \%$ \\
\hline $\mathrm{f}$ & Tidak menjawab & 3 & $10 \%$ \\
\hline
\end{tabular}

Berdasarkan beberapa kendala tersebut, maka ada beberapa harapan dari pengelola BUMDes yang perlu dilakukan dalam rangka pengembagan BUMDes kearah lebih baik adalah perlu dilakukan pelatihan, bimbingan teknis dalam menyusun rencana usaha dan pembukuan. Harapan mereka 
tersebut tertuang dalam kuesioner pelatihan yang hasilnya dapat diuraikan dalam tabel berikut ini.

Tabel 8

Solusi Untuk Mengatasi Masalah BUMDes

\begin{tabular}{|c|c|c|c|}
\hline No & Faktor Penghambat & $\mathrm{F}$ & $\begin{array}{l}\text { Prosen } \\
(\%)\end{array}$ \\
\hline $\mathrm{a}$ & $\begin{array}{l}\text { Pelatihan, Bimtek rencana } \\
\text { usaha dan pembukuan }\end{array}$ & 21 & $73 \%$ \\
\hline $\mathrm{b}$ & $\begin{array}{l}\text { Penyertaan modal dari } \\
\text { pemerintah dan masyarakat }\end{array}$ & 5 & $17 \%$ \\
\hline $\mathrm{c}$ & $\begin{array}{lr}\text { Kemudahan } & \text { dalam } \\
\text { mendapatkan } & \text { pinjaman } \\
\text { modal } & \end{array}$ & 0 & $0 \%$ \\
\hline \multirow[t]{2}{*}{$\mathrm{f}$} & Tidak menjawab & 3 & $10 \%$ \\
\hline & Jumlah & 29 & $100 \%$ \\
\hline
\end{tabular}

\section{Keadaan Kegiatan Pelatihan}

Kegiatan pelatihan keuangan BUMDes dilakukan dilaksanakan pada tanggal 05 Oktober 2021 bertempat di Kantor Desa Temmapaduae. Kegiatan tersebut difasiitasi oleh Pemerintahan Kecamatan Marusu dan Pemerintah DesaTemmapaduae. Peserta pelatihan merupakan pengelala BUMDes yang berjumlah sebanyak 30 orang dan 5 BUMDes di Kecamatan Marusu Kabupaten Maros (Daftar Hadir Peserta terlampir). Pelaksana kegiatan sebanyak 8 orang yang terdiri dari dosen dan mahasiswa program studi Akuntansi STIEM Bongaya.

\section{a. Acara Pembukaan}

Acara pembukaan pelatihan dipandu oleh salah satu tim dosen STIEM Bongaya yakni Ibu Nur Azizah Basmar, S.E., M.Acc., selaku MC (Master of Ceremony). Penyampaian kata sambutan dalam acara pembukaan diawali oleh dari pimpinan STIEM Bongaya diwakili oleh salah satu anggota Tim yakni Ibu Dr. Hj. Marwah Yusuf, S.E., M.M., Ak, CA. Mengawal sambutannya beliau menyampaikan salam dan permohonan maaf dari pimpinan STIEM Bongaya yang tidak sempat hadir dalam kegiatan tersebut. Beliau menyampaikan bahwa STIEM Bongaya merupakan salah satu lembaga pendidikan di bidang ekonomi, tentunya berperan dalam membantu pemerintah untuk melakukan pemberdayaan ekonomi masyarakat. Sehingga kegiatan ini merupakan wujud atas kepedulian STIEM Bongaya dalam memberikan kontribusi nyata untuk mengembangkan BUMDes sebagai salah satu unit dalam menggerakan roda perekonomian di Desa. Mengakhiri sambuatanya beliau menyampaikan ucapan terima kasih dan penghargaan kepada bapak Camat Marusu yang diwakili oleh bapak Sekcam Marusu yang telah menyediakan 
fasiltas dan sarana pelatihan serta mendatangkan peserta untuk mengikuti kegiatan pelatihan tersebut. Serta dibantu oleh kepala desa Temmapaduae

Penyampaian kata sambutan selanjutannya oleh Sekcam Marusu, Kepala Desa Salenrang mewakili Camat Marusu sekaligus membuka acara pelatihan tersebut. Dalam sambutannya, Sekcam menyampaikan bahwa kegiatan ini sangat membantu melakukan pemberdayaan ekonomi masyarakat melalui BUMDes. Lebih lanjut beliau menyampaikan BUMDes di Kecamatan Marusu sangat pontensial dikembangkan. Khususnya pada Desa Temmapaduae salah satu jenis usaha BUMDes yakni usaha pengelolaan sampah dan briket menjadi usaha unggulan. Beliau berharap kegiatan ini bisa dapat ditindaklanjuti dalam bentuk bimbingan teknis sehingga pengelola BUMDes lebih terampil dalam mengelola keuangan BUMDes.

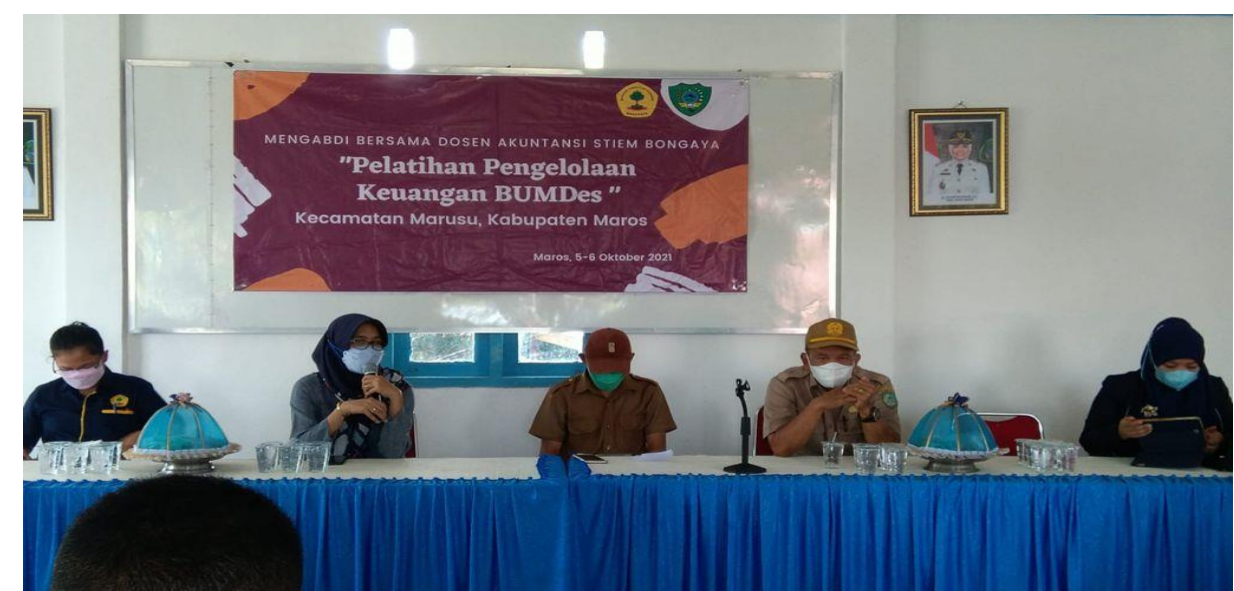

Gambar 2. Kata Sambutan dari Ibu Dr. Hj. Marwah Yusuf, S.E., M.M., Ak, CA mewakili Pimpinan STIEM Bongaya

\section{b. Penyajian Materi dan Diskusi}

Kegiatan penyajian materi pelatihan pengelolaan keuangan BUMDes dipandu oleh satu Tim Dosen yaitu Ibu Nur Azizah Basmar, S.E., M.Acc., selaku moderator. Pemateri dalam kegiatan tersebut adalah Ibu Dr. $\mathrm{Hj}$. Marwah Yusuf, S.E., M.M., Ak, CA dan Ibu Dr. Eva Marin Sambo, S.E., M.M., Ak., CA. Dan ada tiga dosen yang berperan sebagai pengamat yaitu Ibu Lusiana Kanji, S.E., M.Si., Ak., CA, Bapak Anwar, S.E., M.Si., dan Ibu Musdalifah, S.E., M.Ak. Kemudian dibantu oleh tiga mahaswa yaitu Riska Amalia, M. Iksan, dan Pricillia Angela Mega, yang berperan meregistrasi peserta dan mengarahkan peserta untuk mengisi kuesioner kegiatan.

Moderator dalam mengawali membicaraannya beliau menyampaikan kegiatan ini merupakan salah satu bentuk pengabdian kepada masyarakat dari dosen dan mahasiswa program studi Akuntansi STIEM Bongaya. Penyajian materi dalam bentuk panel dengan metode ceramah dengan durasi waktu penyajian materi kurang lebih 10 menit setiap materi. 
Kemudian dilanjutkan dengan sesi diskusi dan tanya jawab. Penyajian materi pertama oleh Bapak Ibu Dr. Hj. Marwah Yusuf, S.E., M.M., Ak, CA dengan judul : Pengenalan BUMDes dan Meyusun Rencana Bisnis. Pokok bahasan yang diuraikan terdiri dari ;

a. Regulasi tentang BUMDes

b. Pengertian BUMDes

c. Pentingnya BUMDes,

d. Perbedaan BUMDes dan Usaha Lain,

e. Tujuan pendirian BUMDes,

f. Bidang usaha BUMDes,

g. Cara dan tahapan mendirikan BUMDes,

h. Organisasi dan pegawai BUMDes,

i. Permasalahan BUMDes,

j. Menyusunan rencana bisnis BUMDes.

k. Contoh menyusun rencana bisnis BUMDes

Kemudian penyajian materi kedua oleh Dr. Eva Marin Sambo, S.E., M.M., Ak., CA dengan judul : Teknik Pembukuan Keuangan BUMDes. Pokok bahasan matri terdiri dari:

a. Pengertian pembukuan/akuntansi BUMDes

b. Tujuan pembukuan atas traksaksi keuangan BUMDes

c. Pengelompokan traksaksi BUMDes

d. Pengumpulan bukti transaksi

e. Proses pembukuan BUMDes

f. Sistem akuntansi/pembukuan BUMDes

g. Memulai melakukan pembukuan BUMDes (Contoh dan simulasi)

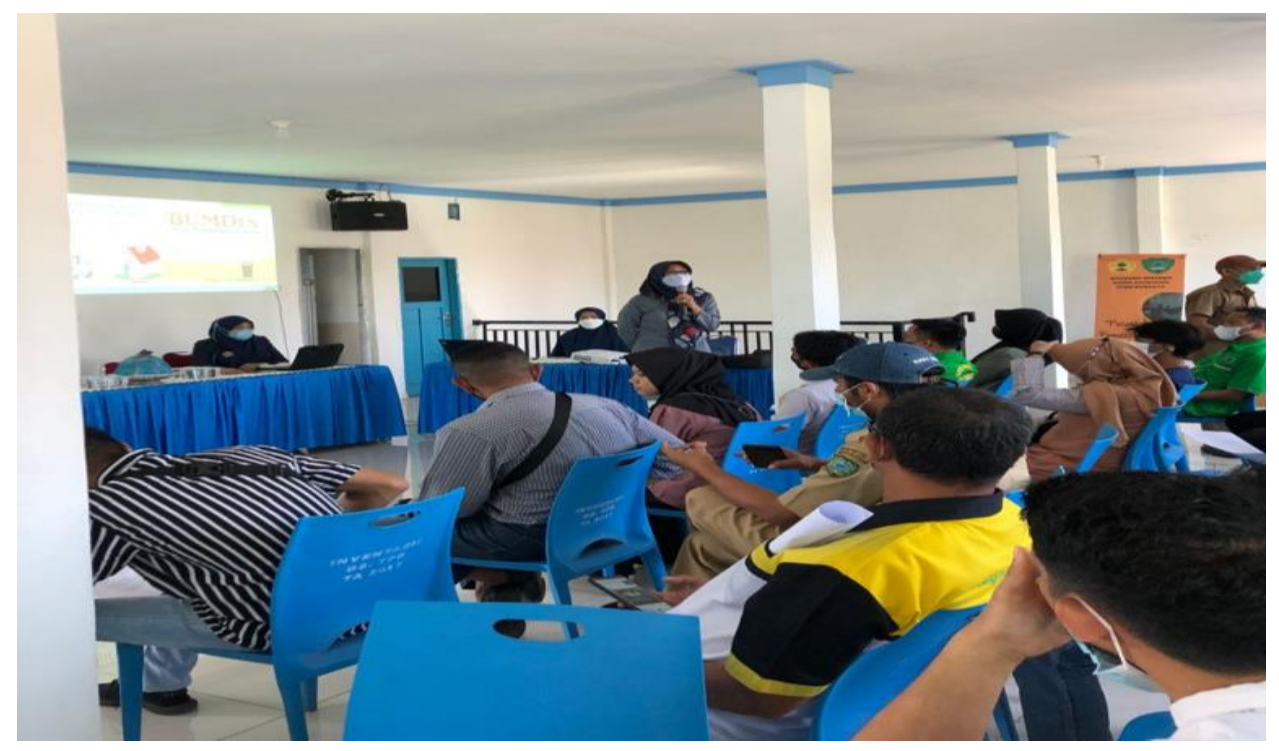

Gambar 3. Materi -Materi Pelatihan oleh Pemateri

Berdasarkan pengamatan menunjukkan bahwa para peserta sangat antusias dalam mengikuti kegiatan pelatihan. Hal ini dapat dilihat dari 
keberadaan mereka dalam forum mulai dari acara pembukaan sampai selesainya kegiatan. Kemudian beberapa peserta ketika dibuka sesi diskusi memberikan tangggapan bahwa kegiatan ini sangat baik bagi mereka. Menurut peserta pelatihan kegiatan ini telah memberikan banyak manfaat, diantaranya adalah: meningkatkan kemampuan mengelola BUMDes, mempermudah mengelola BUMDes. Seperti yang terungkap dalam pengisian kuesioner saat pelatihan.

Tabel 9

Manfaat Pelatihan

\begin{tabular}{|c|c|c|c|}
\hline No & Faktor Penghambat & $\mathrm{F}$ & $\begin{array}{l}\text { Prosen } \\
(\%)\end{array}$ \\
\hline $\mathrm{a}$ & $\begin{array}{l}\text { Meningkatkan kemampuan } \\
\text { mengelola BUMDes }\end{array}$ & 20 & $69 \%$ \\
\hline $\mathrm{b}$ & $\begin{array}{l}\text { Mempermudah mengelola } \\
\text { BUMDes }\end{array}$ & 6 & $21 \%$ \\
\hline $\mathrm{c}$ & Tidak bermanfaat & 0 & $0 \%$ \\
\hline \multirow[t]{2}{*}{$\mathrm{d}$} & Tidak menjawab & 3 & $10 \%$ \\
\hline & Jumlah & 29 & $100 \%$ \\
\hline
\end{tabular}

Peserta setelah mengikuti ulasan atas materi yang dijelaskan baik oleh pemateri dan tambahan penjelasan dari tim dosen yang lain, maka ada bebrapa harapan mereka agar kegiatan ini dapat dtindaklanjuti dalam bentuk yang lebih teknis yakni dilakukan pelatihan dan bimbingan, khususnya dalam hal pengelolaan pembukuan keuangan BUMDes. Hal ini seperti terungkap dari hasil analisis pengisian kuesioner berikut ini :

Tabel 10

Tindak Lanjut Kegiatan Pelatihan

\begin{tabular}{clcc}
\hline No & Faktor Penghambat & F & $\begin{array}{c}\text { Persen } \\
(\%)\end{array}$ \\
\hline $\mathrm{a}$ & Cukup dengan sosialisasi & 0 & $0 \%$ \\
\hline $\mathrm{b}$ & $\begin{array}{l}\text { Sosialisasi diikuti dengan } \\
\text { pelatihan }\end{array}$ & 1 & $4 \%$ \\
\hline $\mathrm{c}$ & $\begin{array}{l}\text { Sosialisasi ikuti dengan } \\
\text { pelatihan dan Bimtek }\end{array}$ & 25 & $86 \%$ \\
\hline $\mathrm{d}$ & Tidak menjawab & 3 & $10 \%$ \\
\hline & Jumlah & 29 & $100 \%$ \\
\hline
\end{tabular}




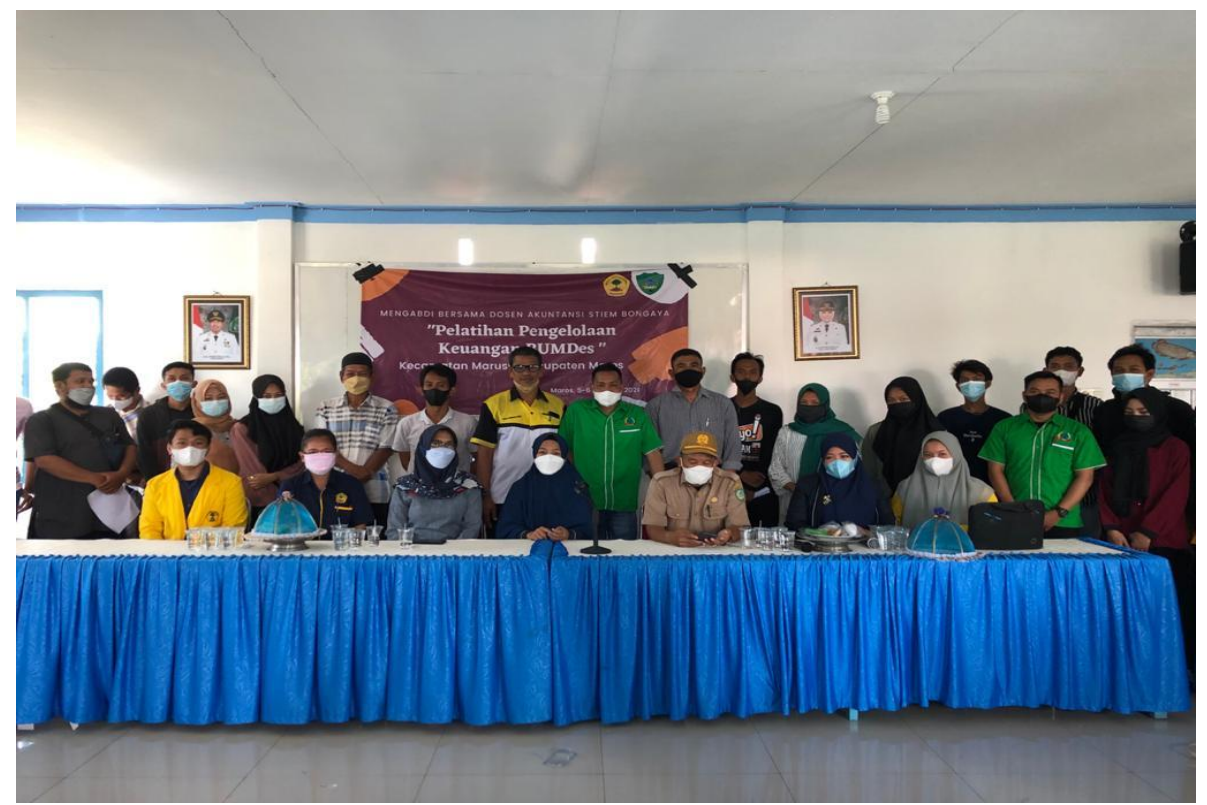

Gambar 4. Tim dan Peserta Pelatihan BUMDes di Kecamatan Marusu

\section{c. Studi Wisata dan Wisata Kuliner}

Setelah kegiatan penyajian materi berakhir, tim pengabdian masyarakan melakukan kunjungan wisata. Kunjungan ini bermaksud untuk mengamati secara langsung salah satu jenis usaha BUMDes yang ada desa Selenrang Kecamatan Bontoa yakni Wisata Ramang.

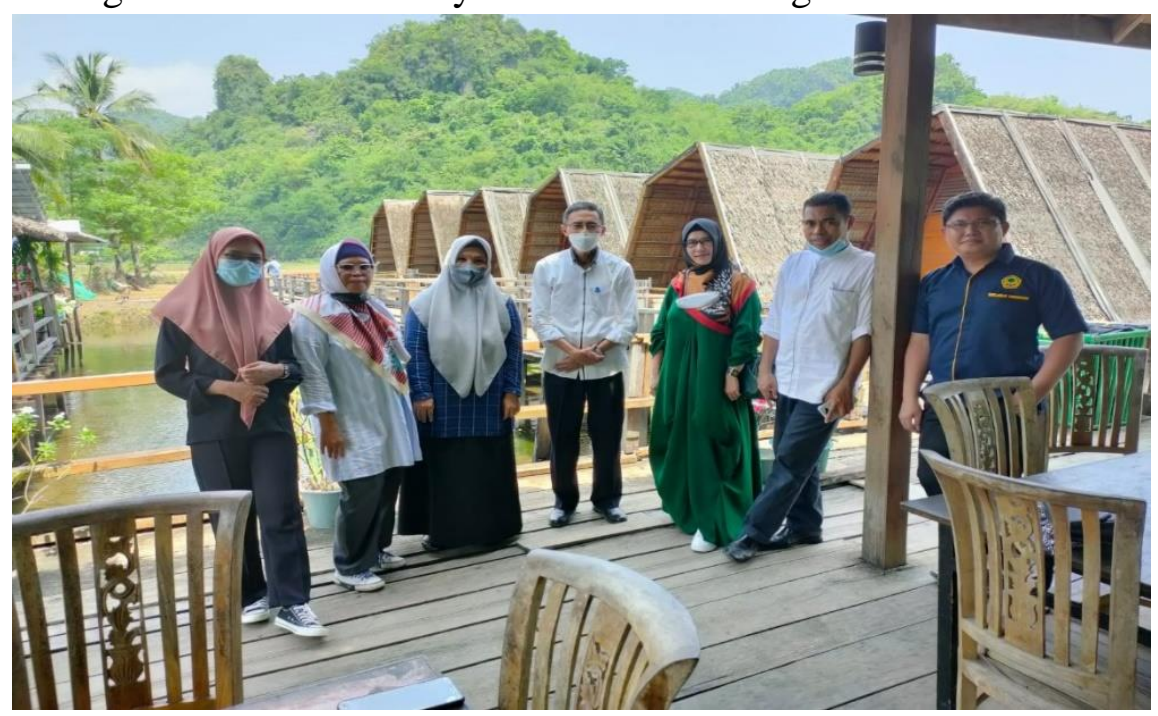

Gambar 5. Studi Wisata di Wisata Ramang (salah satu jenis usaha BUMDes)

Sebagai akhir dari kegiatan tim pengabdian masyarakat melakukan wisata kuliner sekaligus makan siang di salah satu tempat kuliner di Kabupaten Maros 


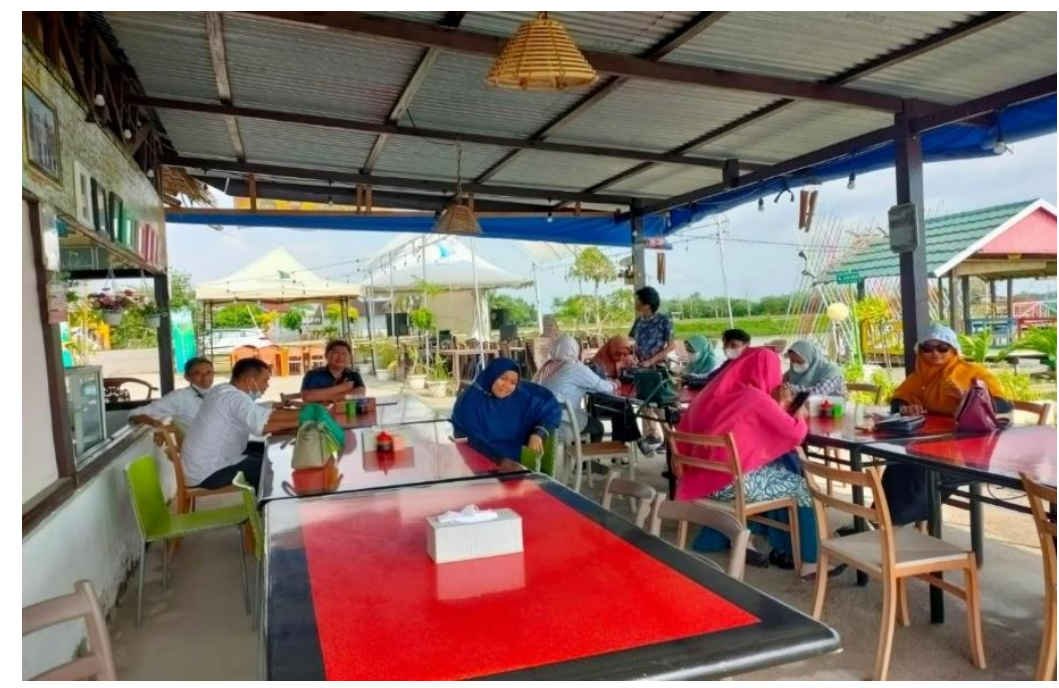

Gambar 6. Wisata Kuliner di Kabupaten Maros dan Makan Siang

\section{Kesimpulan}

Perkembangan BUMDes telah berjalan dengan baik dan keberadaan BUMDes telah banyak memberikan manfaatkan bagi masyarakat setempat. Pengelolaan keuangan BUMDes sebagian besar masih menggunakan sistem pembukuan manual. Terdapat beberapa kendala dalam pengelolaan BUMDes yaitu kemampuan SDM yang masih rendah, pangsa pasar barang/jasa yang dihasilkan BUMDes masih terbatas, kurangnya permodalan, tidak memiliki rencana usaha dan sistem pembukuannya belum baik. Dengan dilakukannya kegiatan pelatihan memberikan manfaat dalam meningkatkan kemampuan dan kemudahan dalam mengelola BUMDes. Tindak lanjut kegiatan diharapkan lebih teknik dalam bentuk pelatihan dan bimbingan teknis terkait dengan penyusunan rencana usaha dan teknik

\section{Ucapan Terimakasih}

Terima kasih banyak kepada Camat dan Kepala Desa di Kecamatan Marusu dan seluruh pihak yang membantu dalam tulisan ini.

\section{Daftar Pustaka}

Abidin, M. Z. (2015). Tinjauan Atas Pelaksanaan Keuangan Desa dalam Mendukung Kebijakan Dana Desa. Jurnal Ekonomi \& Kebijakan Publik, 6 (1), 61-76.

AlSukri, S., Prihastuti, A. H., \& Julina, J. (2020). Pelatihan Laporan Keuangan Bagi Pengurus BUM Desa Sekapur Sirih. To Maega: Jurnal Pengabdian Masyarakat, 3(2), 130-141.

Buku Panduan Pendirian dan Pengelolaan Badan Usaha Milik Desa (BUMDes). (2007). Pusat Kajian Dinamika Sistem Pembangunan Fakultas Ekonomi Universitas Brawijaya, Malang

Didiharyono, D., Tenrigau, A. M., \& Marsal, M. (2018). Pemanfaatan Sampah Plastik Untuk Dijadikan Bantal Yang Berkualitas Dan Bernilai Ekonomis 
Di Desa Tolada Kecematan Malangke Kabupaten Luwu Utara. To Maega: Jurnal Pengabdian Masyarakat, 1(1), 8-13.

Fadila, A., Sholihah, D. R., \& Nugraheni, S. (2021). Pembinaan Pengelolaan Keuangan dan Pemasaran Digital pada pelaku UKM Kecamatan Ciomas Bogor. To Maega: Jurnal Pengabdian Masyarakat, 4(2), 221-230.

Fitriadi, Y., Novita, W., \& Endriani, D. (2021). Ekonomi Kreatif Sebagai Solusi Bagi Keluarga Pra Sejahtera Untuk Bertahan Dalam Era New Normal. To Maega: Jurnal Pengabdian Masyarakat, 4(1), 35-46.

Pedoman Pengabdian Pada Masyarakat STIEM Bongaya. (2019). Pusat Penelitian dan Pengabdian Masyarakat STIEM Bongaya

Peraturan Pemerintah Republik Indonesaia Nomor 11 Tahun 2021 Tentang Badan Usaha Milik Desa (BUMDes)

Peraturan Menteri Desa, Pembangunan Daerah Tertinggal, dan Transmigrasi Republik Indonesia Nomor 3 Tahun 2021 Tentang Pendaftaran, Pendataan dan Pemeringkatan, Pembinaan dan Pengembangan, dan Pengadaan Barang dan/atau Jasa Badan Usaha Milik Desa/Badan Usaha Milik Desa Bersama.

Slamat, F. R., Ishak, I., Salampessy, M. J., \& Kaliky, F. S. (2021). Edukasi Penyusunan Laporan Keuangan Badan Usaha Milik Negeri (BUMneg) Ulihalawang Hitumessing. To Maega: Jurnal Pengabdian Masyarakat, 4(2), 115-123.

Sujarweni, V.W., \& MerthaJaya, I.M. (2020). Pengelolaan Keuangan Bumdes Sambimulyo di Kawasan Geoheritage "Tebing Breksi” Yogyakarta. Jurnal Ilmiah Padma Sri Kreshna, 1(2), 13-17

Suriyati, S. (2019). Desain Perancangan E-Commerce Kain Tenun Lombok Desa Sukarara Lombok Tengah.To Maega: Jurnal Pengabdian Masyarakat, 2(2), 63-70.

Undang - Undang Nomor 32 tahun 2004 tentang Pemerintahan Daerah Undang - Undang Nomor 6 Tahun 2014 Tentang Dana Desa

Yusuf, M., Wahyu, W., Anwar, A., \& Alam, S. (2021). Peningkatan Ekonomi Masyarakat Melalui Pembuatan Pola Ruang. To Maega: Jurnal Pengabdian Masyarakat, 4(1), 71-80. 